\title{
Smallholder rubber agroforestry farming in the non-traditional areas of Sri Lanka: An application of assets-based livelihood capital indicator approach
}

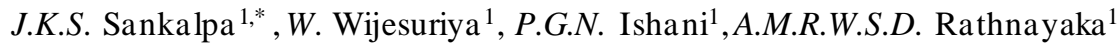 \\ ${ }^{1}$ Rubber Research Institute of Sri Lanka, Dartonfield, Agalawatta, 12200, Sri Lanka
}

\begin{abstract}
This study focuses on Livelihood Capital Index $(L C I)$ as a useful tool in assessing the livelihood assets of rubber-based agroforestry farm households. It evaluates systematically all the livelihood capitals of rubber agroforestry farm households through developing an LCI. A total of 10 livelihood assets variables were broadly classified into five livelihood capital indicators namely; human, financial, physical, natural, and social. Data collected from 220 farm households through a questionnaire survey were normalized to construct five livelihood capital indicators and LCI. The appropriate weights for the livelihood capital indicators were assigned based on the principal component analysis (PCA). The average composite $L C I$ was 0.49 for rubber-based agroforestry farm households and the human capital corresponds to the highest livelihood assets indicator (0.15) followed by financial (0.14), social (0.11), physical (0.05), and natural (0.05). The highest average $L C I$ was reported by the rubber-based groundnut practice $(0.54)$ followed by rubber-based cattle (0.53), cocoa (0.51), passion fruit $(0.51)$, pepper (0.49), maize (0.49), and banana (0.48). Except for physical capital, it also indicates a statistically significant difference in livelihood capital indicators among the rubber agroforestry farmers and other income earners. A significant difference exists in the livelihood capital indicators except for human capital among the Divisional Secretariat. The outcome of this study suggests that the use of $L C I$ is a more analytically rigorous comprehensive tool that can assess the livelihood of rubber agroforestry farmers and enable them to be improved their livelihood assets.
\end{abstract}

Keywords: Rubber-based agroforestry; household; Livelihood Capital Index; Principal Component Analysis

\section{Introduction}

Planting food crops as the intercrops in natural rubber (Hevea brasiliensis Mull Arg.) lands may contribute to household food security. Approximately $90 \%$ of global rubber production comes from Asian countries, and Sri Lanka is the $14^{\text {th }}$ largest producer of Hevea rubber in the world as of the year 2020 [1]. Sri Lankan rubber is mainly produced by the

\footnotetext{
* Corresponding author: ssankalpa2@gmail.com
} 
smallholding sector from the extent of 138,300 ha [1]. Rubber cultivation was initiated in the British period centred in the Western Province of Sri Lanka. Moneragala District, a nontraditional region for rubber (situated in the Uva province) was selected for rubber cultivation in the early 1990s. Despite the sharp volatility of rubber prices in global markets, demand for rubber is growing due to its significant contribution to the improvement of rural farm livelihoods. Rubber agroforestry practices were mainly introduced with rubber cultivation at the immature phase of rubber to compensate for the financial requirements of smallholder farmers until beginning latex harvesting.

The expansion of rubber cultivation into non-traditional areas have been generated several benefits including thinly populated land (the higher ratio of land to man), high land pressure in the traditional rubber growing areas, low incidences of diseases reported, and improvement of rural livelihood [2]. Farmers in the traditional rubber growing areas are cultivating several food crops including tea, bana na, cinnamon, pepper, and pineapple with rubber. It is reported that increasing the input efficiency of food crops is vital to minimize competition for resources with rubber and the application of proper agronomic practices is most vital in ensuring the input efficiency of food crops [3]. Adding food crops cultivation to the rubber lands gives more benefits, except for crop yield such as increasing nitrogen a vailability in soil, reducing soil erosion, and plant support to control crop pests $[4,5]$.

The sustainable livelihood analysis framework consists of five components including livelihood assets, vulnerability context, transforming structures and processes, livelihood strategies and livelihood outcomes [6]. This sustainable livelihood analysis framework consists of the five livelihood capitals including human capital (skills, knowledge, and health), Financial capital (income and savings), Physical capital (basic infrastructure), social capital(social resources and networks), and natural capital(natural resources such as water, air, land). The ability to choose different livelihood strategies by smallholder farmers are impacted by the characteristics of their livelihood assets. It is important to know about the adaptation strategies based on the livelihood assets to maintain a diverse structure of livelihood choices and enhancing livelihood resilience [7, 8].

Literature reveals that the livelihood choices are impacted by the livelihood assets of the households [9]. Also, access to livelihood capitals by farm households improves their farm management abilities and boost their entrepreneurial competencies [10]. Farmers have a higher capacity to cultivate more capital-intensive crops when they have higher financial capital and they have more opportunities to improve awareness and develop more skills with good social capital [9]. Farmers can alleviate poverty when they have good access to household livelihood capitals [11]. A diversity of smallholder rubber production systems in terms of endowments in livelihood capitals, performance and efficiency was reported in a study conducted to analyse the role of livelihood capitals in rubber farming in Thailand. The authors also highlighted that most diversified rubber practice involves higher livelihood capitals [12]. The use of livelihood capitals to analyse the existing status of smallholder farming was reported in various studies including the decision on planting [13], livelihood assets on sustainable development [14] livelihood assets on food security [15].

This study focuses to analyze the characteristics of livelihood capitals of smallholder farmers who practised rubber-based agroforestry and it aims to identify the existing status concerning the livelihoods assets as input variables.

\section{Material and methods}

\subsection{Study Area}

Moneragala District was selected as the study area since it was the first District in the non traditional areas where the rubber agroforestry commenced. Also, a higher diversity of 
rubber agroforestry practices is evident in the Moneragala District. The study area is located between $6^{\circ} 27^{\prime}$ to $6^{\circ} 57^{\prime} \mathrm{N}$ and $81^{\circ} 28^{\prime}$ ' to $80^{\circ} 55^{\prime} \mathrm{E}$ (Fig. 1).

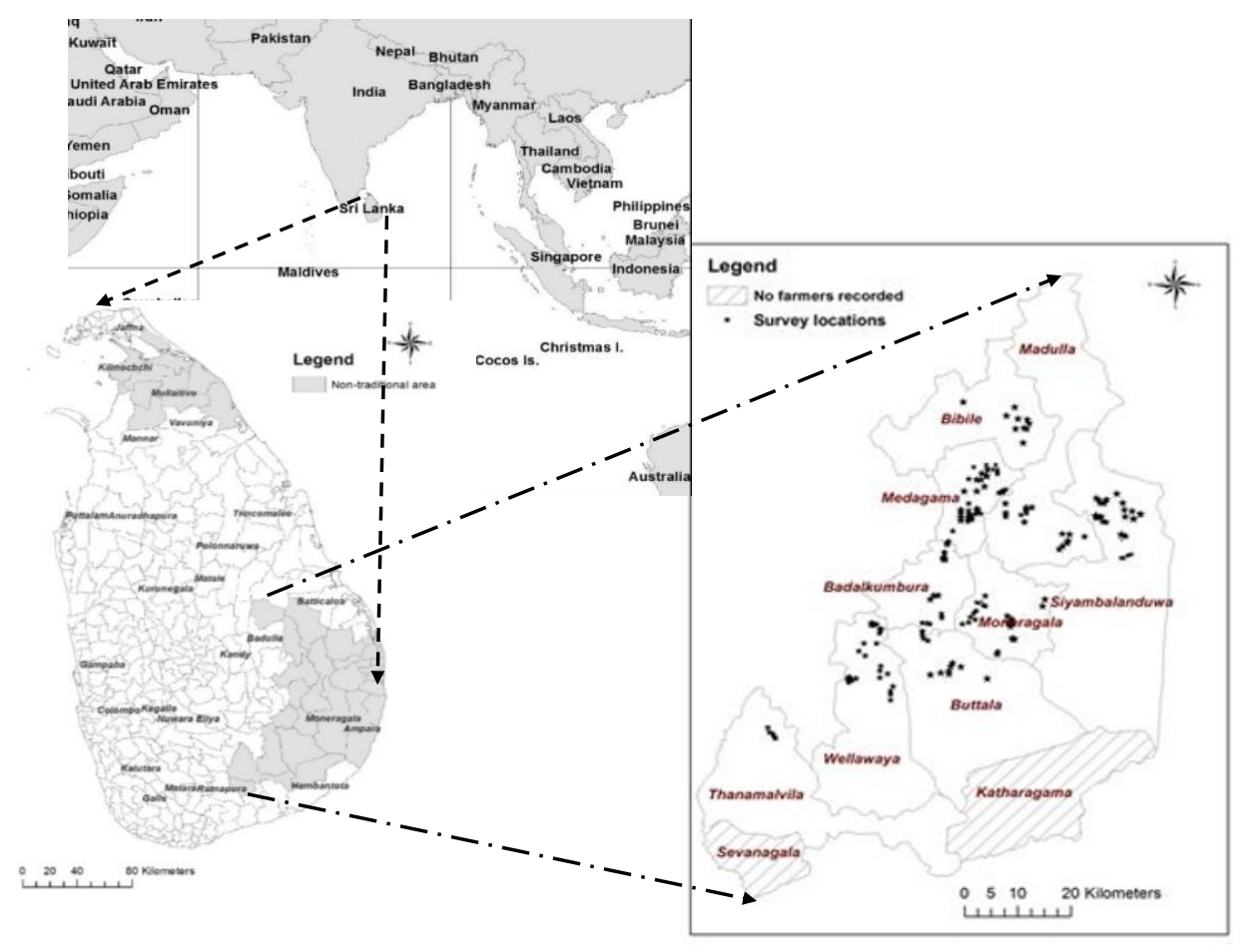

Fig. 1. Location of the study area (source: Rubber Research Institute of Sri Lanka)

\subsection{Sampling, variable selection, and data collection}

The information falling into households and farming systems variables (Table 1) were collected using a structured questionnaire. About 1,300 farmers practised rubber-based agroforestry according to the census conducted by the Rubber Research Institute with the help of the International Fund for Agricultural Development (IFAD). The stratified random sampling technique was adopted employing eight Divisional Secretariat (DS) Divisions as strata: Namely A. Badalkumbura (20), B. Bibile (6), C. Buttala (10), D. Madulla (27), E. Medagama (54), F. Moneragala (43), G. Siyambalanduwa (28), and H. Wellawaya (32).

Variables falling into five livelihood capitals and sociodemographic information of the farm households were collected (Table 1). Also, relevant literature cited for justification of the selection of each variable were shown in Table 1. A positive relationship is expected between the higher per-capita land area and natural capital while a negative relationship with the age of rubber trees. The potential for rubber-based agroforestry reduces with the maturity of rubber trees. Higher education of farm household head or education of the members of the household have been considered to favour the human capital. Adult fa mily members in a particular household provide high labour capacity in agriculture. The adult male and female has been mostly considered as more capacity to provide family labour. The relationship between the cost of cultivation with financial capital is expected to be negative. The percentage of investment in any particular activity by a household can be considered as an indicator of household savings. When higher the distance from farmland to a major road, lower the infrastructural facilities. Therefore, the distance from land to the 
road should be a negative relationship with the physicalcapital. Social connections made by the farm household were considered as a positive relationship with the social capital of the household.

Table 1. Variables selected for the study

\begin{tabular}{|c|l|l|}
\hline \multicolumn{1}{|c|}{ Type } & \multicolumn{1}{|c|}{ Indicator } & \multicolumn{1}{c|}{ Literature } \\
\hline Sociodemographic information & Gender, Age. Education & \\
\hline Livelihood capitals & \multicolumn{1}{|c|}{ Ancome, Annual } & {$[9,16,12]$} \\
\hline Financial & $\begin{array}{l}\text { Annual } \\
\text { investment in farming }\end{array}$ & {$[9,17,16,12]$} \\
\hline Human & $\begin{array}{l}\text { Number of years of formal } \\
\text { education } \\
\text { Adult family members }\end{array}$ & {$[18,16]$} \\
\hline Natural & $\begin{array}{l}\text { Per capita cropland, age of the } \\
\text { rubber trees }\end{array}$ & {$[19,20]$} \\
\hline Social & $\begin{array}{l}\text { Number of societies involved } \\
\text { annually, time duration (hours) } \\
\text { per month spent with the societies }\end{array}$ & $\begin{array}{l}\text { Distance to a major road, } \\
\text { Percentage investment on } \\
\text { machinery }\end{array}$ \\
\hline Physical & $\begin{array}{l}\text { Rubber agroforestry and other } \\
\text { agricultural income }\end{array}$ & $\begin{array}{l}\text { Rubber agroforestry and non-farm } \\
\text { income }\end{array}$ \\
\hline Livelihood strategies & Rubber agroforestry income & \\
\hline
\end{tabular}

\subsection{Livelihood capital indicator approach}

\subsection{Normalization of variables}

Ten variables were selected falling into livelihood capitals. Our indicator approach is in line with the sustainable livelihood framework which was developed by the DFID. The normalization of variables was done as described in the literature $[22,23,24]$ to make it comparable since the variables are in a different scale and unit. Eq. 1 can be used for the variable that influences positively on livelihood capital for the normalization while Eq. 2 can be used for the variables that influence negatively on livelihood capitals.

$$
\begin{gathered}
\text { Variable }_{\text {Normalized }}=\frac{\left(\text { Value }_{\text {actual }}-\text { Value }_{\max \text { imum }}\right)}{\left(\text { Value }_{\max \text { imum }}-\text { Value }_{\min \text { imum }}\right)} \\
\text { Variable }_{\text {Normalized }}=\frac{\left(\text { Value }_{\max \text { imum }}-\text { Value }_{\text {actual }}\right)}{\left(\text { Value }_{\max \text { imum }}-\text { Value }_{\min \text { imum }}\right)}
\end{gathered}
$$




\subsubsection{Assigning weights for the livelihood capitals}

A few approaches to assigning weights in the composite indicator building have been reported in the literature. Among them, assigning equal weights, subjective to the expert opinion, and assigning weights based on the statistical methods are the commonly used techniques [22]. Considering the multidimensional nature of the variables and the advantages of the use of a statistical method in assigning weights, we select principal component analysis (PCA) to determine the weights. This statistical methodological approach consists of the following steps: first, the principal component of each variable was analyzed and obtained the percentage of variability of each component and the com ponent score matrix followed by a varimax rotation. The next step was the calculation of the coefficient of each variable in the linear combination of the principal component. The fin a 1 step was the calculation of the coefficient of each variable based on the variance contribution by each component in the comprehensive score.

\subsubsection{Calculation of Livelihood Capital Index (LCI)}

LCI was calculated according to Eq. 3 .

$$
L C I_{i}=\sum_{j=1}^{5} w_{j} L C_{i j}(i \in 1,2, \ldots 220 ; j \in 1,2, . .5)
$$

Where $\mathrm{LCI}_{\mathrm{i}}$ is the livelihood capital index of the $\mathrm{i}^{\text {th }}$ farm household. $W_{\mathrm{j}}$ represents the weight of livelihood capital $j . L C_{\mathrm{ij}}$ represents the livelihood capital $j$ of rubber agroforestry farm household $i$. The $L C I$ generated for rubber agroforestry farm households was compared using the Analysis of variance test (ANOVA) to identify the differences of $L C I$ with the livelihood capital indicators, livelihood strategies, and the location of the agroforestry practices.

\section{Results and discussion}

\subsection{Descriptive results of rubber agroforestry}

The banana was the most companion crop (36\%) cultivated in the Moneragala district followed by cocoa $(17 \%)$, maize $(16 \%)$, pepper (12\%), groundnut $(5 \%)$, passion fruit $(3 \%)$, and dairy cattle (3\%). Dairy cattle farmers are comparatively younger aged farmers while the rubber-based groundnut agroforestry farmers are the oldest. Rubber-based cocoa received the highest annual income (US\$2687) and the income earnings from rubber-based agroforestry practices show a higher variation. The highest annual investment in rubberbased agroforestry is US $\$ 202$ that owns by the rubber-based maize agroforestry practice with a higher variation. Rubber-based groundnut farmers are more educated farmers (years $=10$ ) compared to the other practices.

The average number of years spent in a formal education institute by the household head is above 8 and it is comparatively low for cattle farmers. The highest per capital cultivation land area $(0.78 \mathrm{ha})$ owns by the rubber-based maize practice and the a verage age of rubber trees is 4 years for all the practices except for cocoa (5 years) and pepper (5 years) practices. Participation in the societies and infrastructure facilities for the rubber-based agroforestry farmers is nearly similar. Rubber-banana farmers have invested more finance (48\%) for machinery and equipment than other practices. The lowest investment (2\%) on 
machinery is reported by the rubber-pepper practice. Rubber-based cattle farmers solely depend on rubber-based agroforestry income while rubber-based groundnut farmers $(36 \%)$ and rubber-maize farmers (19\%) receive the highest other farming income and non-farm income into their annualfarm income.

\subsection{Livelihood capital index of rubber agroforestry practices}

The five livelihood capitals indicate different weights based on the PCA analysis results. The weight assigned to the livelihood capitals is given in Table 2. Figure 2 shows the Livelihood Capital Index $(L C I)$ of the rubber-based agroforestry farm households. The average $L C I$ of farm households is 0.49 and it varies from 0.31 to 0.71 . The mean $L C I$ is just bellowing the cut-off margin, which is 0.5 . Only about $8 \%$ of farm households are less than 0.40 in the $L C I$ while the $L C I$ of $39 \%$ of farm households varies from 0.40 to 0.49 . The $L C I$ of $46 \%$ of farm households varies from 0.5 to 0.59 while it is about $6 \%$ for the $L C I$ above 0.6 . Accordingly, $L C I=>0.51$ for nearly half of the rubber-based agroforestry farm households.

Table 2. Estimated weight of the livelihood capital and indicators

\begin{tabular}{|l|l|l|}
\hline $\begin{array}{l}\text { Livelihood } \\
\text { capital }\end{array}$ & Weight & \multicolumn{1}{c|}{ Indicator } \\
\hline Natural & 0.14 & Age of rubber trees $(0.12)$, Per capita crop area (0.02) \\
\hline Physical & 0.14 & Percentage investment in machinery $(0.07)$, Access to a major road $(0.07)$ \\
\hline Financial & 0.25 & Total annual income $(0.11)$, Annual investment on cultivation $(0.13)$ \\
\hline Human & 0.3 & Education of household head $(0.10)$, Adult members in household $(0.20)$ \\
\hline Social & 0.17 & $\begin{array}{l}\text { Number of societies participated }(0.10), \text { Hours per month spent with societies } \\
(0.07)\end{array}$ \\
\hline
\end{tabular}

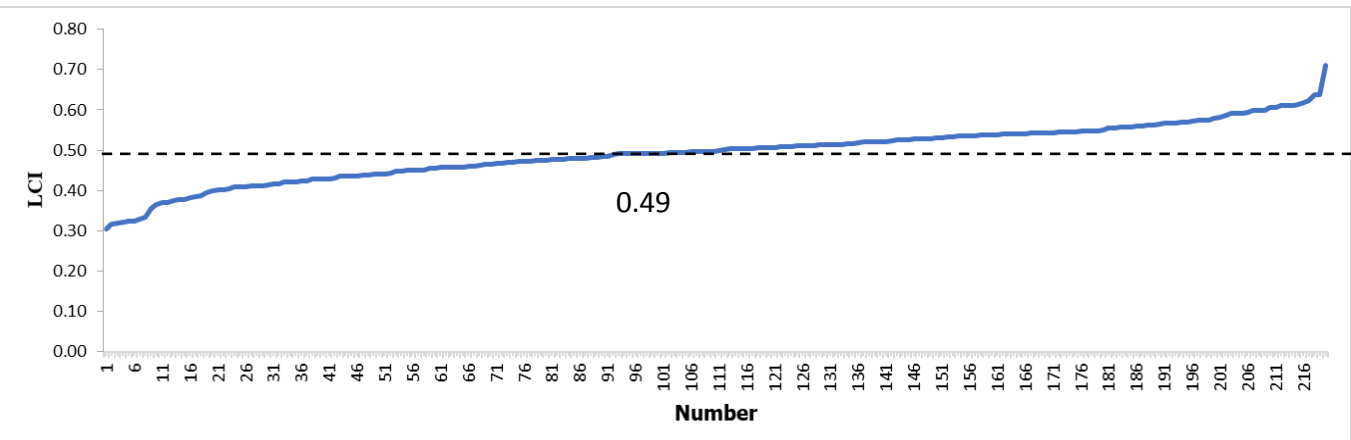

Fig. 2. LCI of rubber-based agroforestry farm households

Fig. 3 shows the variation of five livelihood capitals in the selected rubber-based agroforestry farm households. The five livelihood capitals clearly show that the contribution of human and financial sub-indexes is comparatively higher for all the practices. The human capital sub-index varies from 0.13 (cattle) to 0.17 (groundnut and cocoa) while it varies from 0.13 (banana, groundnut, maize, passion) to 0.15 (other; cowpea, pineapple, vegetable varieties) for the financial capital sub-index. The physical capital sub-index varies from 0.04 (maize, pepper and other) to 0.07 (dairy cattle) while it also varies from 0.04 (banana and cocoa) to 0.07 (cattle, groundnut, and maize) for the natural capital sub-index. For the social capital sub-index, it varies from 0.10 (pepper and cocoa) to 0.12 (cattle, groundnut). LCI of each rubber-based agroforestry practice is presented in Table 3. Rubber-based agroforestry shows a variation in terms of their 
implications in the livelihood capitals. The livelihood strategy is said to be significantly affected by the livelihood capitals of the farm household.

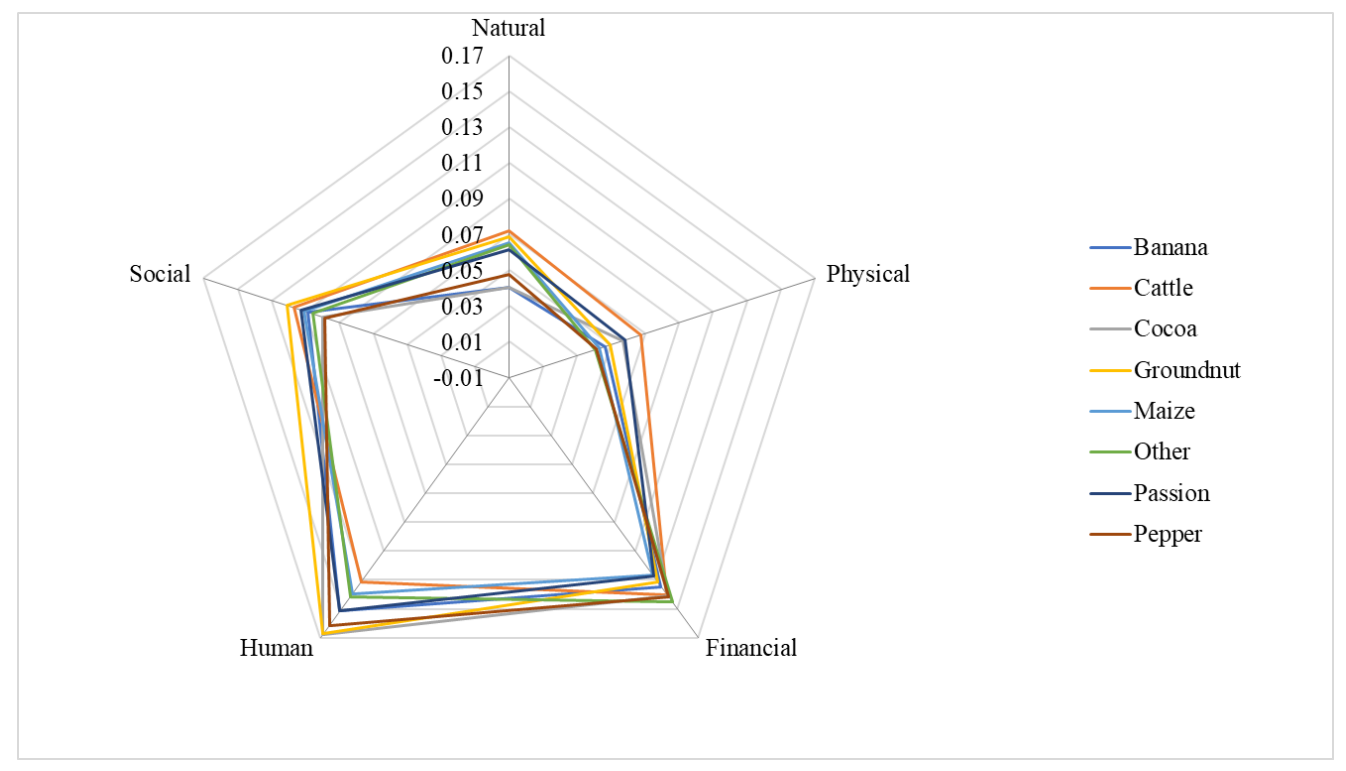

Fig. 3. $L C I$ of rubber-based agroforestry practices

Table 3. Descriptive statistics of LCI

\begin{tabular}{|l|l|l|l|c|}
\hline Rubber agroforestry & Mean & Max & Min & Standard deviation \\
\hline Banana & 0.48 & 0.61 & 0.32 & 0.06 \\
\hline Cattle & 0.52 & 0.63 & 0.39 & 0.09 \\
\hline Cocoa & 0.50 & 0.71 & 0.32 & 0.08 \\
\hline Groundnut & 0.53 & 0.63 & 0.49 & 0.04 \\
\hline Maize & 0.48 & 0.61 & 0.31 & 0.07 \\
\hline Passionfruit & 0.51 & 0.59 & 0.41 & 0.07 \\
\hline Pepper & 0.49 & 0.59 & 0.32 & 0.06 \\
\hline Other & 0.49 & 0.59 & 0.3 & 0.07 \\
\hline
\end{tabular}

\subsection{Livelihood capital indicators and the rubber-based agroforestry practices}

Table 4 shows characteristics and differences of livelihood capital indicators of rubberbased agroforestry practices. No significant difference exists in the annual income generation from rubber agroforestry among the farm households. However, a statistically significant $(p=0.07)$ difference exists in the total annual investment in rubber agroforestry which indicates the savings of each rubber agroforestry practice (since higher annual investment means lower savings and annual investment values were normalized based on negative effect). Other agroforestry (cowpea, vegetable, pineapple. etc.), dairy cattle and pepper agroforestry practices were characterized by higher savings compared to other 


\section{RUBIS 2021}

practices. Both physical capital indicators, percentage investment in machinery $(p=0.001)$ and distance to a major road $(p=0.01)$ indicate a significant difference among the farming practices. Both indicators, per capita cropland $(\mathrm{p}=0.02)$ and age of rubber trees $(\mathrm{p}=0.001)$ can be used to differentiate eight rubber-based a groforestry practices.

Table 4. Comparison of livelihood capital indicators by rubber-based agroforestry practice

\begin{tabular}{|c|c|c|c|c|c|c|c|c|c|}
\hline $\begin{array}{l}\text { Capital } \\
\text { indicator }\end{array}$ & $\begin{array}{l}\text { Banana } \\
(\mathrm{n}=80)\end{array}$ & $\begin{array}{l}\text { Cattle } \\
(\mathrm{n}=6)\end{array}$ & $\begin{array}{l}\text { Cocoa } \\
(\mathrm{n}=37)\end{array}$ & $\begin{array}{c}\text { Groundnut } \\
(\mathrm{n}=12)\end{array}$ & $\begin{array}{l}\text { Maize } \\
(\mathrm{n}=36)\end{array}$ & $\begin{array}{c}\text { Passion } \\
\text { fruit }(n=6)\end{array}$ & $\begin{array}{l}\text { Pepper } \\
(\mathrm{n}=26)\end{array}$ & $\begin{array}{c}\text { Other } \\
(\mathrm{n}=17)\end{array}$ & p-value \\
\hline \multicolumn{10}{|l|}{ Financial } \\
\hline $\begin{array}{l}\text { Total } \\
\text { annual } \\
\text { income }\end{array}$ & 0.008 & 0.01 & 0.012 & 0.01 & 0.007 & 0.006 & 0.011 & 0.011 & 0.431 \\
\hline $\begin{array}{l}\text { Annual } \\
\text { investment } \\
\text { in } \\
\text { cultivation }\end{array}$ & 0.121 & 0.124 & 0.123 & 0.116 & 0.114 & 0.116 & 0.124 & 0.128 & $0.07 *$ \\
\hline \multicolumn{10}{|l|}{ Physical } \\
\hline $\begin{array}{l}\text { Percentage } \\
\text { investment } \\
\text { in } \\
\text { machinery }\end{array}$ & 0.003 & 0.013 & 0.011 & 0.018 & 0.008 & 0.012 & 0.001 & 0.004 & $0.001 * * *$ \\
\hline $\begin{array}{l}\text { Distance to } \\
\text { a major } \\
\text { road }\end{array}$ & 0.043 & 0.054 & 0.046 & 0.03 & 0.034 & 0.045 & 0.041 & 0.037 & $0.01 * * *$ \\
\hline \multicolumn{10}{|l|}{ Human } \\
\hline $\begin{array}{l}\text { Education } \\
\text { of } \\
\text { household } \\
\text { head }\end{array}$ & 0.044 & 0.031 & 0.052 & 0.055 & 0.052 & 0.045 & 0.045 & 0.037 & 0.31 \\
\hline $\begin{array}{l}\text { Adult } \\
\text { members in } \\
\text { farm } \\
\text { household }\end{array}$ & 0.108 & 0.102 & 0.117 & 0.113 & 0.088 & 0.107 & 0.117 & 0.106 & 0.19 \\
\hline \multicolumn{10}{|l|}{ Natural } \\
\hline $\begin{array}{l}\text { Per capita } \\
\text { crop land }\end{array}$ & 0.001 & 0.002 & 0.001 & 0.001 & 0.003 & 0.001 & 0.001 & 0.001 & $0.02 * *$ \\
\hline $\begin{array}{l}\text { Age of } \\
\text { rubber trees }\end{array}$ & 0.039 & 0.072 & 0.039 & 0.068 & 0.063 & 0.062 & 0.047 & 0.064 & $0.001 * * *$ \\
\hline \multicolumn{10}{|l|}{ Social } \\
\hline $\begin{array}{l}\text { Number of } \\
\text { societies }\end{array}$ & 0.082 & 0.098 & 0.078 & 0.095 & 0.086 & 0.093 & 0.071 & 0.086 & $0.095^{*}$ \\
\hline $\begin{array}{l}\text { Hours spent } \\
\text { in societies } \\
\text { per month }\end{array}$ & 0.023 & 0.015 & 0.018 & 0.021 & 0.021 & 0.017 & 0.023 & 0.011 & 0.635 \\
\hline
\end{tabular}

Note: One-way analysis of variance (ANOVA) test was performed to compare $L C I$ values $* * *$ significant at $99 \%$ confidence level; $* *$ significant at the $95 \%$ confidence level; * significant at the $90 \%$ confidence level

No significant difference among the groups was observed for the educational attainment by the household head. This is mainly due to a lower variation of school attainment by a household head. It is reported that the adaptability in the innovation of 
farming is positively linked with their education [25]. It's further highlighted that farmers with proper education possess the ability to manage technologies and use the information.

\subsection{Livelihood capital indicators and livelihood strategies}

Table 5 gives results for livelihood capital indicators by major household income source. Except for the total annual income generated by farm the household, all the other livelihood capital indicators were non-significant among the two categories. As presented in Table 6, the statistically significant difference $(P=0.08)$ exists between the two groups and the mean of the indicator of annual investment (higher savings) shows a mong the rubber agroforestry farm households who primarily depend on agroforestry income. The difference in the primary income of both groups statistically significant $(P=0.08)$ and the mean of the indicator are marginally high among the rubber agroforestry households who depend primarily on non-farm or other agricultural income earnings activities. Higher per capita cropland livelihood capital of rubber agroforestry $(P=0.04)$ indicates accessibility to land and one of the major determinants of crop diversification. Farmers with large land extents are more likely to cultivate different crop combinations [26] and this is also true regarding the rubber agroforestry.

Table 5. Comparison of livelihood capital indicators by major household income source

\begin{tabular}{|l|c|c|c|}
\hline Capital indicator & $\begin{array}{c}\text { Rubber } \\
\text { agroforestry }\end{array}$ & $\begin{array}{c}\text { Other agricultural } \\
\text { income and non- } \\
\text { farm income }\end{array}$ & p-value \\
\hline Financial & & & \\
\hline Total annual income & 0.009 & 0.012 & $0.08^{*}$ \\
\hline Annual investment in cultivation & 0.122 & 0.114 & $0.02^{* *}$ \\
\hline Physical & & & 0.005 \\
\hline Percentage investment in machinery & 0.007 & 0.04 & 0.3 \\
\hline Distance to a major road & 0.041 & & 0.94 \\
\hline Human & & 0.04 & 0.81 \\
\hline Education of household head & 0.04 & & $0.05^{* *}$ \\
\hline Adult members in farm household & 0.10 & & \\
\hline Natural & & 0.001 & $0.04^{* *}$ \\
\hline Per capita crop land & 0.002 & 0.049 & 0.98 \\
\hline Age of rubber trees & 0.049 & & \\
\hline Social & & 0.081 & $0.07^{*}$ \\
\hline Number of societies & 0.088 & 0.021 & 0.95 \\
\hline Hours spent in societies per month & 0.021 & & \\
\hline
\end{tabular}

Note: One-way analysis of variance (ANOVA) test was performed to compare LCI values

$*$ Significant at $90 \%$ confidence level, $* *$ significant at $95 \%$ confidence level

Apart from the income generated from the rubber-based farming systems, farmers in the area had income from other agricultural activities and rural non-farm income generation. Other agricultural income activities in Moneragala District mainly include the cultivation of paddy, mono-cropping of maize, cowpea, and banana, a variety of vegetables, cassava, and watermelon. Although income from non-farm activities plays a crucial role in livelihoods, it is reported as a barrier to potential adoption in agricultural innovations by 


\section{RUBIS 2021}

farmers. Literature reveals that this incidence is providing more off-farm employment diverting human capital away from agriculture [27]. A marginal but statistically significant difference exists between the two groups for the number of societies participated by the head of household. Participation in the societies by farm household heads is important on various fronts such as knowledge sharing, establishing volunteer groups in basic infrastructure development, formulation of micro-credit programmes. Participation in the societies helps farmers to share their experiences, knowledge on agronomic practices use in rubber agroforestry. It is important to improve the social capital of farmers since the overa 11 awareness of agronomic practices are comparatively low in the Moneragala District [2].

\subsection{Regional comparison of livelihood capital indicators}

Table 6. Regional comparison of livelihood capital indicators

\begin{tabular}{|c|c|c|c|c|c|c|c|c|c|}
\hline Capital indicator & $\begin{array}{c}\mathrm{A} \\
(\mathrm{n}=20)\end{array}$ & $B(n=6)$ & $\begin{array}{c}\mathrm{C} \\
(\mathrm{n}=10)\end{array}$ & $\begin{array}{c}\mathrm{D} \\
(\mathrm{n}=27)\end{array}$ & $\begin{array}{c}E \\
(n=54)\end{array}$ & $\begin{array}{c}F \\
(n=43)\end{array}$ & $\begin{array}{c}\mathrm{G} \\
(\mathrm{n}=28)\end{array}$ & $\begin{array}{c}\mathrm{H} \\
(\mathrm{n}=32)\end{array}$ & $P$-value \\
\hline \multicolumn{10}{|l|}{ Financial } \\
\hline $\begin{array}{l}\text { Total annual } \\
\text { income }\end{array}$ & 0.009 & 0.007 & 0.01 & 0.009 & 0.01 & 0.008 & 0.005 & 0.006 & $0.03 * *$ \\
\hline $\begin{array}{l}\text { Annual investment } \\
\text { in cultivation }\end{array}$ & 0.11 & 0.13 & 0.12 & 0.11 & 0.12 & 0.12 & 0.11 & 0.12 & $0.03 * *$ \\
\hline \multicolumn{10}{|l|}{ Physical } \\
\hline $\begin{array}{l}\text { Percentage } \\
\text { investment in } \\
\text { machinery }\end{array}$ & 0.002 & 0.0001 & 0.022 & 0.008 & 0.006 & 0.007 & 0.009 & 0.002 & $0.002 * * *$ \\
\hline $\begin{array}{l}\text { Distance to a major } \\
\text { road }\end{array}$ & 0.04 & 0.03 & 0.05 & 0.03 & 0.04 & 0.04 & 0.02 & 0.03 & $0.001 * * *$ \\
\hline \multicolumn{10}{|l|}{ Human } \\
\hline $\begin{array}{l}\text { Education of } \\
\text { household head }\end{array}$ & 0.05 & 0.01 & 0.04 & 0.05 & 0.04 & 0.04 & 0.05 & 0.04 & 0.133 \\
\hline $\begin{array}{l}\text { Adult members in } \\
\text { farm household }\end{array}$ & 0.09 & 0.12 & 0.12 & 0.1 & 0.11 & 0.1 & 0.1 & 0.09 & 0.365 \\
\hline \multicolumn{10}{|l|}{ Natural } \\
\hline $\begin{array}{l}\text { Per capita crop } \\
\text { land }\end{array}$ & 0.003 & 0.001 & 0.001 & 0.002 & 0.001 & 0.002 & 0.003 & 0.002 & $0.02 * *$ \\
\hline Age of rubber trees & 0.04 & 0.02 & 0.04 & 0.05 & 0.04 & 0.05 & 0.06 & 0.04 & $0.004 * * *$ \\
\hline \multicolumn{10}{|l|}{ Social } \\
\hline $\begin{array}{l}\text { Number of } \\
\text { societies }\end{array}$ & 0.05 & 0.02 & 0.04 & 0.05 & 0.04 & 0.05 & 0.06 & 0.04 & $0.004 * * *$ \\
\hline $\begin{array}{l}\text { Hours spent in } \\
\text { societies per month }\end{array}$ & 0.01 & 0.01 & 0.01 & 0.02 & 0.02 & 0.01 & 0.02 & 0.02 & $0.03 * *$ \\
\hline
\end{tabular}

Note: One-way analysis of variance (ANOVA) test was performed to compare $L C I$ values $* *$ Significant at $95 \%$ level, $* * *$ Significant at $99 \%$ level

Except for the adult members and the education of the household head, all the other livelihood capital indicators show a statistically significant difference among the eight regions (Table 6). Turning into the livelihood capital indicators, high potential for rubber agroforestry due to immature rubber trees and higher per-capita crop areas, higher 
percentage investment on machinery shows among the rubber-based agroforestry households in the Siyambalanduwa (G) DS. Also, a higher number of societies participated by the household head is significantly higher among the farm ers who live in the Buttala (C) DS. While the highest cultivation cost on rubber agroforestry shows among the farmers in Siyambalanduwa (G) DS and the lowest cost or the higher savings represents among the farmers in Bibila (B) DS. Farmers in the Buttala (C) region have good infrastructural facilities compared to other regions this is mainly due to the proximity of rubber lands to the roads and thereby good accessibility. In terms of the number of societies participated by the farm household heads and the total annual income generated by the farm household $\mathrm{s}$ in the region of Medagama (E)DS shows a significantly higher indicator value.

\section{Conclusion}

Livelihood capitals based $L C I$ provides a way to identify the livelihood development status of agroforestry farm households. About half of the households in the study area are above the cut-off margin of $L C I$. Except for the human capital indicators, other $L C$ indicators shows a significant variation among the rubber agroforestry practices. Rubber agroforestry and other income earners are significantly differentiated based on their LC indicators except for physical capital. Also, regional differences exist among rubber agroforestry in terms of $L C$ indicators except for human capital. The findings are useful for agri-extension workers and policymakers to address livelihood development issues of rubber agroforestry farmers in non-traditionalareas.

\section{References}

1. [ANRPC] Association for natural rubber producing countries, $7^{\text {th }}$ Floor, Bangunan Getah Asli (Menara), 148, Jalan Ampang, 50450 Kuala Lumpur, Malaysia (2020).

2. W. Wijesuriya, K. Herath, V. Abeywardene. Bulletin of the Rubber Research Institute of Sri Lanka 46:1-9 (2005).

3. L.S.S. Pathiratna. Bulletin of the Rubber Research Institute of Sri Lanka 47: 8-16 (2006).

4. M. Van Noordwijk, G. Cadisch, C.K. Ong. CAB International(2004).

5. Z.R. Khan, J.A. Pickett, J.V.D. Berg, L.J. Wadhams, C.M. Woodcock. Pest Management Science 56,11:957-962 (2000).

https://doi.org/10.1002/1526-4998(200011)56:11<957::AID-PS236>3.0.CO;2-T

6. [DFID] Department for InternationalDevelopment. London, UK (2000).

7. Y.P. Fang, F.B. Zhu, X.P. Qiu, S. Zhao. Habitat Int. 76: 19-28 (2018). https://doi.org/10.1016/j.habitatint.2018.05.004

8. J. Forster, I.R. Lake, A.R. Watkinson, J.A. Gill. Mar. Policy. 45: 204-212 (2014). https://doi.org/10.1016/i.marpol.2013.10.017

9. B. Wei, G. Su, Y. Li, Y. Ma. Sustainability 11, 5905 (2019). https://doi.org/10.3390/su11215905

10. E. Mumuni, O.I. Oladele. Agric \& Food Security 5, 1 (2016). https://doi.org/10.1186/s40066-015-0049-X

11. [FAO] Food and Agricultural Organization. Socio-economic and livelihood analysis in investment planning. [Online] from http://www.fao.org/3/bq859e/bq859e.pdf (2008) [accessed on January 122020 ]

12. O. Longpichai, S.R. Perret, G.P. Shivakoti. Outlook on Agriculture 41,2:117-124 (2012). https://doi.org/10.5367\%2Foa.2012.0085

13. L. Yang, M. Liu, F. Lun, Q. Min, W. Li. Land Use Policy 86: 208-217 (2019). https://doi.org/10.1016/j.landusepol.2019.04.030 
14. W. Li, C. Shuai, Y. Shuai, X. Cheng, Y. Liu, F. Huang. J. Int. Dev. 32: 408-429 (2020). https://doi.org/10.1002/jid.3461

15. A.O. Manlosa, J. Hanspach, J. Schultner, I. Dorresteijn, J. Fischer. Food Sec. 11: 167181 (2019). https://doi.org/10.1007/s12571-018-00883-x

16. P.B. Bhandari. J Rural Stud. 1-32: 126-136 (2013). https://doi.org/10.1016/j.jrurstud.2013.05.001

17. W. Ding, S.O. Jimoh, Y. Hou, X. Hou, W. Zhang. Sustainability 10: 3325 (2018). https://doi.org/10.3390/su10093325

18. Z.H.A.O. Wenjuan, Y.A.N.G. Shilong, W.A.N.G. Xiao. Asian Agricultural Research 8,3: 17-21 (2016). https://ageconsearch.umn.edu/record/242475

19. F. Mancini, A.V. Bruggen, J. Jiggins. Experimental Agriculture 43:97-112 (2007). https://doi.org/10.1017/S001447970600425X

20. L.A.O. Fernandes, P.J. Woodhouse. Ecological Economics 66, 2-3:243-257 (2008). https://doi.org/10.1016/j.ecolecon.2008.01.027

21. H. You, X. Hu, B.C. Chenmeng, D. Zhou. Discrete Dynamics in Nature and Society 9631701 (2019). https://doi.org/10.1155/2019/9631701

22. S. Kumar, A. Raizada, H. Biswas, S. Srinivas, M. Biswajit. Ecolo. Indicators 70:507517 (2016). https://doi.org/10.1016/j.ecolind.2016.06.041

23. R.B. Kale, K. Ponnusamy, A.K. Chakravarty, R. Sendhil, A. Mohammad. Ind. J. of Ani. Sci. 86,6:720-725 (2016).

24. R. Sendhil, J. Ankita, A. Kumar, S. Singh. Ecological Indicators 89C:771-780 (2018). https://doi.org/10.1016/j.ecolind.2018.02.053

25. S. J. Staal, I. Baltenweck, M. M. Waithaka, T. D. Wolff, L. Njoroge. Agricultural Economics 27:295-315 (2002). https://doi.org/10.1016/S0169-5150(02)00075-0

26. C. Makate, R. Wang, M. Makate, N. Mango. SpringerPlus 5,1:1135 (2016). https://doi.org/10.1186/s40064-016-2802-4

27. I. Daskalopoulou, A. Pretrou. Journal of Rural Studies, 18:95-103 (2002). https://doi.org/10.1016/S0743-0167(01)00027-4 